\title{
SUBJETIVIDADES
}

\section{O Contemporâneo}

à Luz da Psicanálise

e-ISSN: 2359-0777

\section{A POLÍTICA DAS IMAGENS E A ÉTICA DO DESEJO NAS AUTORREPRESENTAÇÕES CONTEMPORÂNEAS}

The Image Policy and the Ethics of Desire in Contemporary Self-Representations

La Política de las Imágenes y la Ética del Deseo en las Auto representaciones Contemporáneas

La Politique de l'Image et l'Éthique du Désir dans les Représentations Contemporaines de Soi

doi) $10.5020 / 23590777 . r s . v 20$ iEsp2.e10428

Raimundo Benone de Araújo Pedrosa Filho 9
Mestre em Psicologia pela Universidade de Fortaleza (Unifor). Graduado em Psicologia pela Universidade de Fortaleza.

Leônia Cavalcante Teixeira 9

Doutora em Saúde Coletiva pela Universidade do Estado do Rio de Janeiro em cotutela com a Universidade Paris Nord - Paris 13 (2001-CAPES). Professora Titular do PPG em Psicologia da Universidade de Fortaleza.

\section{Resumo}

Este artigo debruça-se sobre a articulação entre psicanálise e arte contemporânea, ressaltando a dimensão política desses campos aqui compreendidos como espaços que possibilitam a subversão da lógica homogeneizante de identidades. Nesse sentido, acreditamos que a obra de arte em sua complexidade constitutiva não se reduz a uma verdade tautológica. O objeto e suas imagens suportam uma latência, uma temporalidade sobreposta, operando enquanto ato de sujeito: obra do inconsciente, logo, suportada pela complexa rede de condensações e deslocamentos. Abordaremos certas estratégias de resistência que utilizam as imagens (e as selfies) como instrumento de luta contra os processos de dessubjetivação e assujeitamento. Vislumbraremos possibilidades de novas maneiras de ser e estar no mundo, de novas configurações; aberturas para a diversidade, para a diferença, para a singularidade do sujeito. Nesse sentido, refletiremos sobre a especificidade fotográfica não apenas sob o ponto de vista da crítica da representação, mas também dando destaque para as importantes "políticas da representação", que reafirmam a heterogeneidade nas múltiplas identidades de sujeitos que, ainda hoje, sofrem duras penas por não compactuarem com as normas colonizadoras, sexistas e patriarcais de nossa sociedade.

Palavras-chave: arte; psicanálise; autorrepresentação; política; contemporaneidade.

\section{Abstract}

This article focuses on the articulation between psychoanalysis and contemporary art, highlighting the political dimension of these fields understood here as spaces that allow the subversion of the homogenizing logic of identities. In this sense, we believe that the work of art in its constitutive complexity is not reduced to a tautological truth. The object and its images support a latency; an overlapping temporality, operating as an act of subject: work of the unconscious, therefore, supported by the complex network of condensations and displacements. We will approach certain resistance strategies that use images (and selfies) as an instrument to fight the processes of desubjectivation and subjection. We will see possibilities of new ways of being in the world, of new configurations; openings for diversity, for difference, for the uniqueness of the subject. In this sense, we will reflect on the photographic specificity not only from the point of view of the criticism of representation but also highlighting the important "politics of representation", which reaffirm the heterogeneity in the multiple identities of subjects who, even today, suffer harsh penalties for not complying with the colonizing, sexist and patriarchal norms of our society.

Keywords: art; psychoanalysis; self-representation; politics; contemporaneity. 


\section{Resumen}

Este trabajo se dedica a la articulación entre psicoanálisis y arte contemporánea, enfocando la dimensión política de estos campos comprendidos aqui como espacios que posibilitan la subversión de la lógica homogeneizante de identidades. En este sentido, creemos que la obra de arte en su complejidad constitutiva no se reduce a una verdad tautológica. El objeto y sus imágenes soportan una latencia, una temporalidad sobrepuesta, operando mientras acto de sujeto: obra del inconsciente, luego, soportada por la compleja red de condensaciones y desplazamientos. Enfocaremos ciertas estrategias de resistencia que utilizan las imágenes (y las selfies) como instrumento de luch a contra los procesos de "desubjetivación” y asujetamiento. Vislumbraremos posibilidades de nuevas maneras de ser y estar en el mundo, de nuevas configuraciones; apertura para la diversidad, para la diferencia, para la singularidad del sujeto. En este sentido, reflexionamos sobre la especificidad fotográfica no solo bajo el punto de vista de la crítica de la representación, pero también dando enfoque a las importantes "políticas de la representación", que reafirman la heterogeneidad en las múltiples identidades de sujetos que, todavia hoy, sufren duras penas por no admitieren las normas colonizadoras, sexistas y patriarcales de nuestra sociedad.

Palabras clave: arte; psicoanálisis; auto representación; politica; contemporaneidad.

\section{Résumé}

Cet article se concentre sur l'articulation entre la psychanalyse et l'art contemporain, mettant en évidence la dimension politique de ces champs - entendus ici comme des espaces qui permettent la subversion de la logique d'homogénéisation des identités. En ce sens, nous croyons que l'œuvre d'art, dans sa complexité constitutive, ne se réduit pas à une vérité tautologique. L'objet et ses images supportent une latence, une temporalité imbriquée, fonctionnant comme un acte de sujet : travail de l'inconscient, donc, soutenu par le réseau complexe de condensations et de déplacements. Nous aborderons certaines stratégies de résistance qui utilisent les images (et les selfies) comme instrument pour lutter contre les processus de désubjectivation et d'assujettissement. Nous verrons des possibilités de nouvelles manières d'être et, aussi, d'être au monde, de nouvelles configurations ; ouvertures pour la diversité, pour la différence, pour l'unicité du sujet. Dans ce sens, nous réfléchirons à la spécificité photographique, pas seulement du point de vue de la critique de la représentation, mais aussi en soulignant l'importante "politique de la représentation », qui réaffirme l'hétérogénéité des identités multiples de sujets qui, encore aujourd'hui, subissent de sévères sanctions pour ne pas se conformer aux normes colonisatrices, sexistes et patriarcales de notre société.

Mots-clés : art ; psychanalyse ; auto-représentation ; politique ; contemporanéité.

\section{Autorrepresentação e Empoderamento}

$\mathrm{Na}$ atualidade, as práticas sociais em centros urbanos são mediadas pela tecnologia e crescente visualidade. A emergência das tecnologias da imagem, como a invenção da fotografia e do cinema ainda na segunda metade do século XIX e, mais recentemente, do vídeo e do computador, vem influenciando o modo como a leitura do mundo acontece na sociedade. Presenciamos um fenômeno no qual a quantidade, as modalidades e o intercâmbio de imagens são a cada dia mais numerosos (Miranda, 2007).

Em meio aos desdobramentos do capitalismo global, em que as novas tecnologias da comunicação passam a ser determinantes na construção e manutenção dos laços sociais, construir uma imagem atraente de si em meio a um sem fim de outras imagens, igualmente ávidas por atenção e reconhecimento, torna-se um imperativo. Fazer-se presente imageticamente no mundo virtual revela um "atestado de presença" também no "mundo real", como quem suplica "vejam, eu existo".

É sob esses holofotes que se destacam as representações de si por meio de imagens, em que a selfie surge como emblema principal. Essa prática, amplamente difundida na atualidade, consiste em fotografar a si mesmo por meio de smartphones ou webcams para publicação nas redes sociais digitais.

Foi a partir de meados dos anos 2010 que a difusão dessa modalidade de fotografia ocorreu, quando se popularizou a implantação de câmeras fotográficas na parte frontal de dispositivos eletrônicos, como celulares e tablets. Desde então, a prática das selfies propagou-se enormemente em nossa sociedade, tendo sido, no ano de 2013, eleita a palavra do ano pelo Dicionário Oxford, bem como tema de inúmeras matérias jornalísticas nos mais variados meios de comunicação.

A prática da selfie se mostra, aparentemente, como apenas mais uma moda passageira, que os indivíduos realizam com o único objetivo de diversão e entretenimento. Todavia, ao olharmos para esse fenômeno mais detidamente, perceberemos que 
ele pode ser tomado como um importante veículo de difusão das ideais e dos estilos de vida contemporâneos, ajudando-nos a refletir sobre os modos de ser e estar no mundo em que vivemos.

A psicanálise nos diz que o desejo de reconhecimento atravessa nossa estruturação enquanto sujeitos, como nos alerta Freud (1914/2007a), destacando que necessitamos da presença do outro para nos reconhecermos enquanto eu. Segundo Calligaris (1994), a constituição do sujeito se dá, em princípio, por dois caminhos: por um lado, nos identificamos com os

valores, obrigações, tradições que cada um recebe de sua cultura étnica, nacional, familiar etc. (estas são as identificações simbólicas). Do outro, se esforça para coincidir com a imagem que poderia satisfazer aos outros, onde os anseios parentais ganham lugar de destaque.

Esse esforço, segundo o autor, resume-se ao que, em psicanálise, nomeia-se por narcisismo, sendo este mais incômodo e complexo do que um simples "apaixonamento" pelo próprio rosto (Calligaris, 1994).

$\mathrm{O}$ mito de narciso, teorizado pela psicanálise no começo do século $\mathrm{XX}$, hoje é repensado de modo distinto por teóricos das ciências sociais para definir certos aspectos nos modos de ser e estar no mundo atual. Cristopher Lasch (1983), já na década de 1970, afirmava que vivíamos em uma crescente "sociedade narcísica", em que o lugar de destaque antes ocupado pela neurose e a histeria, no início do século XX, abria espaço para o culto ao indivíduo e para a busca incansável por sucesso pessoal e dinheiro.

Outros importantes pensadores contemporâneos endossam esses pensamentos, reforçando a ideia de que vivemos em um contexto de exacerbação do individualismo e fragilidade nas relações interpessoais. Segundo Lipovetsky e Charles (2004), a "hipermodernidade" - termo designado pelo autor para tratar de nosso tempo - é marcada por uma cultura de excessos, do "sempre mais", na qual se observa o aumento crescente da intensidade e da urgência das coisas, em um movimento acelerado de mudanças que ocorrem em ritmo desordenado. Lipovetsky e Charles (2004) assinala que, na atualidade, as relações reais de proximidade cedem lugar aos intercâmbios virtuais. Assim, assistimos a emergência de uma cultura hedonista e psicologista, que incita a satisfação imediata das necessidades, que estimula a urgência dos prazeres, enaltecendo o florescimento pessoal e colocando o bem-estar, o conforto e o lazer em posição de ideal a ser perseguido pelos indivíduos. Em outras palavras, um estado de plenitude e felicidade inatingíveis.

Quanto à subjetividade, se antes a sociedade exigia fixidez por parte do indivíduo, hoje parece correto afirmar que ela exige fluidez, como bem apontou o pensador polonês Zygmunt Bauman, destacando que, nesse novo cenário, as consequências provenientes do mal-estar devem ser situadas em outro nível. Em O mal-estar da pós-modernidade, Bauman (1998) propõe que, na atualidade, os imperativos culturais não fomentam a renúncia de seus desejos por parte do sujeito, conforme evidenciado por Freud no período moderno. Pelo contrário, prega-se que devemos buscar a satisfação de maneira frenética e imediata. Estamos diante de uma nova era, na qual o homem contemporâneo renuncia a sua parcela de segurança para entregar-se à busca pela felicidade, o que não ocorre sem consequências, pois um grande mal-estar comparece nessa busca incessante pelo bem-estar. A satisfação individual, tão cultuada nos dias de hoje, é acompanhada pelas constantes exigências de mudanças por parte da sociedade, o que ocasiona um sentimento de insegurança generalizado (Bauman, 1998).

Ao pensar acerca das representações de si no mundo contemporâneo, sobretudo no âmbito das novas tecnologias da comunicação - que têm nas redes sociais digitais, talvez, o principal meio de interações entre indivíduos -, Paula Sibilia (2016) propõe a ideia de que hoje assistimos a um verdadeiro "show do eu". A autora aborda a inflação egóica característica de nosso tempo, refletindo sobre as diferentes dimensões do "eu", em especial na internet, a partir das experiências de subjetividade nas quais as dimensões "íntimas" e "confessionais" são pensadas como dirigidas ao outro - construções de si orientadas para uma exposição que objetiva legitimar formas de ser e estar no mundo. Em sua pesquisa, observou a intensa expansão das narrativas (auto)biográficas na contemporaneidade, destacando que a não ficção chama cada vez mais a atenção do público, antes ocupado quase exclusivamente pelas histórias de ficção.

Sibilia (2016) destaca que esse fenômeno corresponde à necessidade crescente e atual de se exibir e se vender como uma espécie de espetáculo, ou seja, quando o indivíduo utiliza os códigos da mídia e da celebridade, a fim de mostrar-se sempre bonito, feliz, bem-sucedido, inteligente, triunfante. Uma espécie de autopromoção que há algum tempo seria considerada de mau gosto, ou mesmo imoral, mas que agora se tornou habitual.

Ao passo em que nos empenhamos em produzir "imagens ideais" de nós mesmos, passamos a consumir, com a mesma ênfase, o universo imagético daqueles com os quais nos identificamos. Enquanto somos atraídos por imagens que se assemelham às nossas idealizações, imagens ideais que construímos de nós mesmos, é possível que adotemos condutas defensivas que rejeitam veementemente o que nos afasta desses ideais. Assim, nos parece problemática a proliferação das barreiras simbólicas que nos separam do outro, uma vez que reduzem o mundo e as possibilidades que o sujeito tem diante dele, que inviabilizam a rica e fundamental experiência de encontro com a alteridade, aquilo que está fora de mim, uma vez que apenas por meio dessa experiência sou capaz de me recriar. 
É precisamente sob esse prisma que trataremos de analisar determinadas formas de estetização do eu na atualidade tecnológica (Pinheiro, 2016), buscando dividir e aprofundar_inquietações. Situaremos um olhar crítico sobre os discursos moralizantes engendrados por instâncias de poder que visam ao controle e à docilização de corpos em nosso tempo.

Embora inúmeros avanços sociais tenham ocorrido nas últimas décadas, vivemos tempos, por exemplo, em que uma grande quantidade de mulheres ainda morrem diariamente vítimas de violência doméstica ${ }^{1}$; tempos em que o número de assassinatos contra pessoas LGBTQ+ no Brasil lideram o ranking mundial ${ }^{2}$. Estes são dados alarmantes, porém reais, que refletem uma sociedade nutrida de intolerância, ódio e preconceitos.

Ser o que se quer e mostrar-se para que o mundo veja, em palavras, gestos, imagens (selfies, por que não?), desafia os discursos visuais machistas, racistas e homofóbicos, operando como instrumento para encontrar novas dimensões na relação entre o pessoal e o social, ao recuperar o controle da visibilidade de corpos habitualmente alienados em representações efetuadas por outros (Prada, 2018).

Embora comumente associada ao narcisismo por grande parte da comunidade científica, as selfies também são defendidas por alguns teóricos como um exercício de liberdade de expressão e como uma forma de empoderamento. Isso revela a impossibilidade de uma definição generalista para um fenômeno tão pungente e complexo, carregado de nuances e paradoxos. O historiador da arte e pesquisador dos estudos visuais Juan Martín Prada (2018) destaca, em sua obra El ver y las imágenes en el tempo de internet, que há um grande número de defensores do possível caráter empoderante das selfies (inclusive atribuindo a elas benéficos potenciais terapêuticos), ao implicar a possibilidade de controlar a imagem que alguém quer mostrar de si mesmo para os demais.

O autor amplia o olhar para essas formas de autorrepresentação, apontando também para seus potenciais enquanto gestos de contravigilância, resultados do direito a produzir imagens do corpo próprio e como alternativa ante a objetivação típica produzida pelo olhar masculino, tal como se dá habitualmente na publicidade ou na pornografia (Prada, 2018).

Esse aspecto dos processos de autorrepresentação que resiste à objetificação dos corpos nos aproxima da ótica que enxerga o compartilhamento de selfies como parte ativa de uma "tecnologia do eu", reconhecendo nessa prática certo potencial subversivo para explorar maneiras alternativas de documentar a vida e o corpo próprios. Conforme nos diz Prada (2018), a selfie também pode ser vista "como um meio para tomar o controle sobre as próprias representações, como uma maneira de idealizar de maneira oposta, contra as pautas hegemônicas da mirada cultural, reivindicando que a autoexposição não seja sempre considerada como prática narcisista ou ególatra" (Prada, 2018, p. 92, tradução nossa).

Diante disso, é possível inferirmos que o fenômeno selfie ultrapassa a leitura que o encerra na ideia de certa inflação egoica movida por um narcisismo exacerbado característico de nossos tempos. Ao buscarmos outros olhares para o fenômeno, novas perspectivas emergem, sendo possível evidenciarmos, por exemplo, que comunidades identitárias minoritárias como a feminista e a queer - resistem às normas dominantes de representação da sexualidade e do gênero por meio de sua presença visual no universo digital. Esses grupos ocupam esses espaços deliberadamente, utilizando-os em sua vinculação com o exercício político de reivindicar visualmente outras possíveis identidades (Prada, 2018).

As selfies, nesse contexto, são utilizadas como ferramenta na resistência às normas dominantes de representação da sexualidade e do gênero, isto é, como um ato em contraposição à mercantilização e à despersonalização do corpo objetivado nas representações dominantes (Prada, 2018). Desse modo, é possível visualizar nessas imagens formas de se apresentar que muitas vezes resultam incompatíveis com as normas politicamente corretas de publicação nas redes sociais majoritárias.

Essas imagens de si configuram um meio complexo de representações e acepções, introduzindo, em meio a essa diversidade de ângulos interpretativos, uma dimensão com potenciais de subversão e de luta contra as convenções representacionais. Selfies como meio para iluminar formas identitárias alternativas. Prada (2018) comenta que:

Fotografar-se sem medo fora dos padrões tradicionais poderia permitir fomentar uma percepção positiva do próprio corpo (um viver felizmente em corpos "imperfeitos"), escapando das inseguranças que dizem respeito à imagem pessoal, mostrando-se sem camuflagens, exibindo uma imagem sem "maquiagens", fora das convenções mainstream, celebrando assim a diferença, a riqueza própria da infinita diversidade corporal. (Prada, 2018, pp. 92-93, tradução nossa)

Circulam, em redes como o Instagram, campanhas que compartilham esses ideais. Imagens que, muitas vezes, vêm acompanhadas de hashtags como \#BodyPositivity, \#BoPo, \#BodyAcceptance ou \#effyourbeautystandards, por exemplo.

1 Em 2016, uma mulher foi assassinada a cada duas horas no país. Fonte: https://www1.folha.uol.com.br/cotidiano/2019/09/brasil-registra-1caso-de-agressao-a-mulher-a-cada-4-minutos-mostra-levantamento.shtml

2 Foram registrados 8.027 assassinatos de pessoas LGBTs no Brasil entre 1963 e 2018, em razão de orientação sexual ou identidade de gênero, segundo o levantamento do Grupo Gay da Bahia. Além disso, de acordo com a ONG Transgender Europe, entre 2008 e junho de 2016 , 868 travestis e transexuais perderam a vida de forma violenta. Fonte: https://www12.senado.leg.br/radio/1/noticia/brasil-e-o-pais-que-mais-mata-homossexuais-no-mundo 
Esse gesto de assumir a sua própria imagem pode também, segundo Prada (2018), tornar-se uma forma de solidariedade entre os usuários, assim como meio para a denúncia política, como já se concretizou em diversas atuações específicas em relação a numerosas circunstâncias.

Assim, reafirmamos a potência que essas imagens adquirem na cultura contemporânea, uma vez que podem ser utilizadas por diversos meios e para diversos fins, inclusive políticos. Somos, desse modo, convocados a ampliar o nosso olhar para questionarmos certas interpretações hegemônicas acerca desse fenômeno e do nosso tempo, reconhecendo nas selfies não apenas um sintoma do capitalismo orientado para o individualismo vaidoso - resultado de uma pedagogia social baseada na cultura da celebridade orientada a depender excessivamente de nosso apelo exterior -, mas também uma possível via de potencial emancipatório para o sujeito.

\section{Psicanálise e Política}

Ao adentrarmos no território da política sob as lentes da psicanálise, é importante sublinharmos que esta não corresponde, ela mesma, a uma política, mas sim a uma ética: a ética do desejo. Sob o prisma psicanalítico, a ética está além de sua acepção clássica, baseada em prerrogativas que visam nutrir a promoção de um ideal de bem comum. Contrapondo-se a essa ideia, a psicanálise aponta para uma desvalorização do desejo, uma vez que aí estão envolvidos aspectos de manutenção de uma moral.

Cabe, nesse ponto, retomarmos uma importante premissa: poder e desejo se opõem, conforme nos ensina Lacan (195960/1988). É possível observarmos no âmbito sociocultural contemporâneo que grande parte da população está orientada para o serviço de bens e consumo, fomentando, assim, a manutenção da perspectiva de sustentação de um poder.

Se retomarmos o "discurso do mestre", conforme teorizou Lacan, teremos como boa ilustração a ideia do "continue trabalhando e não olhe para o seu desejo". Lacan (1959-60/1988), em seu seminário A Ética da Psicanálise, defende a ideia de que o analista em seu ofício se contrapõe às expectativas do sonho burguês, isto é, o de permanecer no conforto. Isto ocorre porque, segundo a tese lacaniana, é necessário que o sujeito renuncie aos bens, ao poder e ao conforto para acessar a zona do desejo.

A política da psicanálise é uma política do sintoma, que, em primeiro lugar, "diz respeito ao sintoma do sujeito, mas, além disso, diz respeito ao questionamento daquilo que faz sintoma com relação aos dispositivos implementados para assegurar o discurso analítico" (Izcovich, 2018, p. 21). A política do sintoma do sujeito distancia-se também da religião, uma vez que a psicanálise opera na direção da satisfação de um desejo, do direito ao gozo. Pode-se dizer, portanto, que "a ética da psicanálise diz respeito à satisfação da pulsão com relação ao desejo" (Izcovich, 2018, p. 21).

Sabemos, desde Freud (1930/2007d), que o mal-estar na civilização está ligado à insatisfação pulsional e que o sintoma seria uma espécie de satisfação substitutiva. Nesse sentido, é possível observarmos que a política tradicional visa tratar o malestar através da identificação, como também aponta Freud (1921/2007c) em Psicologia das massas e análise do Eu, no qual situa que a felicidade e o ideal são fomentadores de identificações. Desse modo, é possível percebermos que o programa da política opera a partir da ideia de que "adquire-se felicidade por se sustentarem os significantes mestres" (Izcovich, 2018, p. 21).

Se é correto dizer que a política está alinhada ao discurso do mestre, uma vez que promove uma identidade aí, é concebível que a psicanálise caminhe em direção oposta, uma vez que preconiza o sujeito marcado pela falta, sendo ele estruturado não por uma identidade, mas pela indeterminação (Izcovich, 2018).

Seguimos com Lacan (1966-1967, inédito), retomando outra importante ideia trabalhada pelo autor: "o inconsciente é política".

Essa afirmação pode ser traduzida, em linhas gerais, como fruto da constatação de que o inconsciente é uma instância de ligação com o Outro, que introduz o sujeito na linguagem por meio da instauração do poder do significante fálico. No entanto o inconsciente não aceita seu estado de servidão. Desse modo, Lacan (1966-1967, inédito) nos indica que o inconsciente é a política, na medida em que é inseparável da existência de um laço com o Outro (Ferretti, 2011).

A política visa ao arranjo, pois "arranja as relações de modo a unificar as modalidades de gozo dos corpos e, para isso, fixa normas e exclui o fora da norma, ou seja, os sintomas" (Izcovich, 2018, p. 22). Se a política, por um lado, propõe a reunificação em torno de um ideal, a psicanálise, por sua vez, "propõe a produção do um por um, o singular" (Izcovich, 2018, p. 22). Amparada por uma ética que leva em consideração a singularidade do sujeito, a psicanálise "supõe um discurso social que implica, na política, a necessidade da democracia" (Izcovich, 2018, p. 25), já que é apenas na democracia que é possível tolerar a pulsão, a qual, por definição, é desviante.

O sujeito é perpassado pelo desejo e pela pulsão e, por isso, é compatível com o projeto democrático, o que implica na necessidade de que a psicanálise reflita sobre o regime político em que sua prática se desenvolve. A psicanálise, antes de ser uma prática que libera, "é uma prática que lança mais luz sobre a condição do sujeito e de seus companheiros. É isso que opõe o exercício de um poder e de confrontar um sujeito aos limites do poder, pois “(...) o exercício de um poder é o oposto da realização de um desejo" (Izcovich, 2018, p. 24). 
A psicanálise opera a partir de um discurso que se opõe à homogeneização dos gozos, contra a indistinção de objetos de gozo para todos, isto é, o mesmo gozo para todos. Essa ideia, baseada na necessidade de escolher para estar consigo aqueles com quem se compartilha o mesmo gozo, "é a barreira das comunidades, sobretudo as religiosas, a base do racismo e da segregação" (Izcovich, 2018, p. 24).

Ao promover a desidentificação, a psicanálise não promove a saída dos discursos, tampouco produz um "fora do discurso". Trata-se justamente do contrário: à medida que se revela a inexistência de harmonia entre os gozos, já que o gozo é sempre do próprio corpo, é a admissão do gozo do Outro que é induzida. "O fato de existir uma comunidade daqueles que compartilham essa perspectiva não constitui nenhum ideal. Trata-se da prova em ato de um discurso diferente daquele que propõe o "cale-se e consuma"' (Izcovich, 2018, p. 24).

A psicanálise e sua ética do desejo colocam em cheque os significantes mestres utilizados para obter obediência coletiva. Logo, se o princípio do mestre é o de "não querer saber", a psicanálise opera no contrafluxo: "você pode saber" (Izcovich, 2018, p. 25). Lacan nos lembra que a ética não é apenas a elucidação do desejo, mas também sua realização, portanto, "a política da psicanálise não é a de fazer uma filosofia, mas de colocar em ação um desejo tendo em vista sua satisfação" (Izcovich, 2018, p. 25).

A política da psicanálise pode ser compreendida como a satisfação do desejo, mas, diferentemente da política, "tratase da satisfação de um desejo que não esteja alienado ao Outro, ou, antes, trata-se de um desejo efeito da desalienação" (Izcovich, 2018, p. 25). Nesse sentido, a psicanálise contribui para recolocar a importância do sujeito e do desejo como algo fundante, inclusive das lógicas sociais. Se a política opera enquanto forma de organização do poder, mostrando que o discurso do mestre pretende foracluir o real, a ética da psicanálise atua de modo contrário, impedindo que o real seja excluído do sujeito e das relações sociais. "A psicanálise faz resistência à dominação abusiva da autoridade e sustenta o preceito de que sempre haverá algo que não poderá ser governado, dito ou entendido, pois o real é o impossível de ser dominado" (Ferretti, 2011, p. 76).

Ainda que haja uma intensificação na incidência da captura imaginária para certo modo de ser e viver na contemporaneidade, voltado à lógica do lucro e à dimensão do gozo, é possível vislumbramos modos diversos de inserção nessa lógica: pessoas que pensam em outros mundos possíveis, outras formas de ser e viver, desafiando as normas que insistem em regular, docilizar e silenciar existências.

\section{Psicanálise, Política e Arte}

A autorrepresentação atravessada por um discurso político de autoafirmação e empoderamento de identidades historicamente rejeitadas pela sociedade nos encaminha a associá-la com certos posicionamentos defendidos por artistas contemporâneos, em especial aqueles identificados, de alguma forma, com lutas sociais. Esses artistas, muitas vezes, utilizam em seus trabalhos o recurso da autodocumentação, do autorretrato e das narrativas de si, "onde o exibicionismo corporal tem sido realizado como parte de um discurso emancipador, capaz de questionar a submissão a certos ditames dominantes sobre o corpo e a sexualidade" (Prada, 2018, p. 92, tradução nossa).

Se, de início, destacamos a psicanálise como um campo híbrido por excelência, estruturado por meio de um profícuo diálogo entre a ciência, a cultura e a história; a arte contemporânea, por sua vez, leva a fundo a ampliação do campo, sustentando seu valor enquanto ato e discurso crítico do seu tempo. Assim, observamos que ambos - psicanálise e arte contemporânea - são campos extremamente "politizados e impuros, e possibilitam a criação de novas formas, pela desconstrução de formas cristalizadas, (trans)formam saberes e singularidades, sublinham o valor do ficcional e do desejo" (Marsillac, Tancredi, \& Sousa, 2018, p. 9).

A arte tem, enquanto atividade humana ligada às manifestações de ordem estética e comunicativa, a capacidade de nos evocar sentimentos múltiplos, questionando, provocando e desestabilizando tudo o que diz respeito ao humano. Nesse sentido, a psicanálise - também enquanto campo de investigação e prática clínica que propõe, desde sua gênese, a desestabilização do eu através do conceito de sujeito do inconsciente - é convocada a refletir, com e a partir da arte, sobre os modos de subjetivação contemporâneos.

A relação entre psicanálise e arte, apesar de se mostrar frutífera, não configura uma relação de completude, em que um saber apresenta-se para tamponar as lacunas do outro. Pelo contrário, essa relação é marcada por pontos de tensões, pela falta, pela incompletude, pela impossibilidade da relação sexual. Falbo (2009) assinala que

não há em Freud ou em Lacan nada que possa ser entendido ou aproximado a uma "teoria da arte". Em suas respectivas teorizações, o pensamento sobre a arte é uma teia que se tece como trama secundária e paralela às questões que a clínica propõe. (p. 74) 
Arte e psicanálise revelam, assim, "tanto familiaridade quanto estranheza". Corroborando essa afirmação, Tânia Rivera (2002) afirma que "não há tranquilidade ou o júbilo das semelhanças, em espelho, do reconhecimento na aproximação entre arte e psicanálise, mas cisão, irrupção da diferença, fragmentação das similitudes" (p. 26). Nesse contexto, "a arte funcionaria como esse olhar que nos vem de outro lugar e que nos traz questões perturbadoras, às vezes até aterrorizantes, que furam ou esburacam tentativas de constituição ou manutenção de um corpo discursivo completo" (Azevedo, 2006, p. 17 Assim, ao recorrermos ao campo da arte para sustentar questões relativas ao nosso campo - a psicanálise - sublinhamos os limites de nosso campo, suas (im)possibilidades, fazendo com que, neste gesto, estejamos submetidos a um certo exercício de castração (Azevedo, 2006).

A opção por esse recorte teórico-metodológico demonstra sua motivação na crença da possibilidade que a arte aponta para psicanálise voltar-se a si mesma, criando novos caminhos, reconstruindo-se. Corroborando Azouri (2014), acreditamos que "é renovando laços com a arte e a criação artística que poderemos retomar a via de reinvenção na psicanálise. A arte e a criação artística são parte do nosso recalcado" (p. 30). Trata-se "de uma relação com o furo, com o vazio no Outro, que o artista, o louco, a mulher e $o$ analisando em fim de percurso - cada um deles à sua maneira - podem encontrar e testemunhar" (Azouri, 2014, p. 30).

Khouri (2015), ao referir-se sobre a articulação psicanálise-arte, afirma que "é no convite ao descentramento do sujeito, na sua errância, nos seus desvios, que está o objeto de busca da psicanálise" (p. 124) e infere, em seguida, que está nesse campo um dos possíveis encontros da psicanálise com a arte contemporânea. A autora assinala ainda que existe "tanto na arte quanto na psicanálise, um constante processo de construção e destruição no qual as articulações entre o dentro e o fora, o sujeito e o objeto, são mediadas pela pessoa do analista ou pela pessoa do artista” (p. 125). Segundo a autora, é aí que "reside a possibilidade da alteridade ser reinaugurada a cada transferência analítica e a cada convocação artística e, assim, não ficarmos reduzidos apenas a nós mesmos" (p. 125).

Ainda sobre essa perspectiva de diálogo entre psicanálise e arte, destacamos que "a arte interessa e ensina o psicanalista justamente por não se conformar a nenhuma regra totalizadora, indicando sem cessar a falha no saber que em torno dela se constrói" (Kosovski, 2016, p. 444). Desse modo, "destacar o espaço vazio no interior da estrutura - o não qualificável que emerge primeiramente como hostil e inaceitável - é fundamental, pois assim se localiza o ponto que permite a abertura para se acolher a diferença e a singularidade" (Kosovski, 2016, p. 445). Assim, enfatizamos que "para que do choque advenha o original, para que o inédito ganhe alguma tradução, é preciso dar tratamento simbólico ao inassimilável e é precisamente neste ponto que a criação artística talvez tenha muito a ensinar à psicanálise" (Kosovski, 2016, p. 452).

O diálogo entre psicanálise e estética atravessa as fronteiras do encontro apaziguador com o belo. De modo mais complexo, a interlocução entre esses campos é repleta de instabilidades: desloca-se entre lugares, buscando o lugar da inquietante estranheza, da falha, do vazio, daquilo que suscita a angústia (Marsillac et al., 2018). Desse modo, pensar na produção de imagens na contemporaneidade, sobretudo no campo da arte, implica um reposicionamento do olhar, uma vez que aquilo que olhamos com dúvida, com surpresa ou estranheza, de algum modo nos devolve o olhar. Conforme destaca o filósofo e historiador da arte Georges Didi-Huberman (1998/2010), “o que vemos aponta para além do princípio de prazer; é o lugar onde ver é perder, e onde o objeto da perda sem recurso, nos olha [e nos interroga]" (p. 227). O autor pontua que a imagem deve ser tomada a partir de suas complexidades, e não reduzida a leituras e interpretações unificantes.

Em O que vemos, o que nos olha (1998/2010), Didi-Huberman aprofunda o conceito de "imagens críticas", privilegiando o aspecto fenomenológico do conceito, "valorando o espaçamento tramado entre o observador e a obra como um lugar onde se abre o imponderável a ser completado e interpretado, ou não, pelo olhante" (Costa, 2009, p. 89). Em contrapartida, a proposta do autor abre caminhos para que pensemos a imagem, bem como sua recepção e produção como uma arena de tensões dialéticas. Um espaço que podemos entender como um "entre": de um lado, o observar e, de outro, a obra que retorna o olhar (Costa, 2009, p. 89).

Não há que escolher entre o que vemos (com sua consequência exclusiva num discurso que o fixa, a saber: a tautologia) e o que nos olha (com seu embargo exclusivo no discurso que o fixa, a saber: a crença). Há apenas que se inquieta com o ENTRE. (...) É o momento em que o que vemos justamente começa a ser atingido pelo que nos olha - um momento que não impõe nem excesso de sentido (que a crença glorifica), nem a ausência cínica de sentido (que a tautologia glorifica). É o momento em que se abre o antro escavado pelo que nos olha no que vemos. (Didi-Huberman, 1998/2010, p. 77)

Nessa passagem, é possível observamos a ênfase dada pelo autor no tocante à dialética presente na experiência com as imagens, instante fugidio em que não há espaço para acepções polarizantes, mas sim uma convocação para um olhar impregnado por uma subjetividade, que olha ao mesmo tempo em que é perpassado pelo olhar que lhe devolve a obra. Diante disso, nos deparamos com a evidência da impossibilidade de um olhar puro, um olhar sem o atravessamento da dimensão do inconsciente. Dito de outro modo, um olho sem sujeito seria uma ilusão (Diógenes, 2017). 
O ato de dar a ver não é o ato de dar evidências visíveis a pares de olhos que se apoderam unilateralmente do "dom visual" para se satisfazer unilateralmente com ele. Dar a ver é sempre inquietar o ver, em seu ato, em seu sujeito. Ver é sempre uma operação de sujeito, portanto uma operação [vulnerável a ser] fendida, inquieta, agitada, aberta. Todo olho traz consigo uma névoa, além das informações de que poderia num certo momento julgar-se o detentor. Essa cisão, a crença quer ignorá-la. (Didi-Huberman, 1998/2010, p. 77)

A partir desse excerto, percebemos que diante das imagens da arte, o ato de ver não se dá sem consequências, uma vez que ao olharmos somos, nesse gesto, também olhados. Algo retorna, provocando em nós ressonâncias, construções simbólicas singulares, e é justamente aí que reside a força das imagens, pois nos apontam aberturas, brechas, possibilidades. Elas convocam o sujeito a cair, a movimentar-se no espaço de uma experiência subjetiva singular.

Em consonância com o pensamento do teórico francês, Tania Rivera (2014) assinala que a arte coloca em cena o sujeito desejante, que resiste aos discursos que visam seu aniquilamento. Nesse gesto de resistir, arte e psicanálise se entrecruzam, denunciando a ilusão do eu estável, fixo, "alienado nas formações imaginárias, amarrado nos discursos ideológicos" (Diógenes, 2017, p. 259). A arte, assim como a psicanálise, evidencia o descentramento do eu, "a falta de garantias da representação, ou seja, o efêmero testemunho da subversão do eu. Isso nos permite pensar a criação como revolta" (Diógenes, 2017, p. 259).

Para Lacan (1959-60/1988), "a obra de arte pode ser uma experiência que, por seu processo, arranca o sujeito de suas amarras psicossociais" (p. 246). Nesse sentido, o autor assinala que a arte é capaz de promover intervenções críticas na cultura, "convocando experiências de subversão e de reflexão sobre o sujeito no mundo" (Diógenes, 2017, p. 259). A criação artística desafia limites, joga com o impensável, com a novidade e com a estranheza. É um espaço de liberdade que propicia a emergência do sujeito desejante na cultura, abrindo caminhos para que ele se movimente, se reinvente. Desse modo, a arte pode ser um canal que possibilita ao sujeito receptor um estranhamento em relação a si mesmo (Rivera, 2014).

No gesto de contemplação, "uma obra seria então uma espécie de armadilha para o sujeito, uma captura deste que estaria, com sua dor e beleza, escondido de si mesmo. Captura do outro no eu, comemorando seu nascimento sempre doloroso, traumático mas efetivo" (Rivera, 2007, p.18). A obra é capaz de capturar o sujeito, e é precisamente nesse momento de entrega, de vertigem diante de uma obra, que se dá o efeito de sujeito, ou seja, a emergência do sujeito (Rivera, 2007).

Mediante o encontro com o objeto artístico, algo se desloca, algo se rompe. Nesse movimento de errância, a ilusão de um eu unificado se desvanece, emergindo a sua finitude, tendo em vista a impossibilidade da segurança representativa. $\mathrm{O}$ sujeito é convocado a cair, a defrontar-se com seus limites e efemeridade. "O sujeito encontra-se convocado a retornar de forma fragmentada, disseminada em não mais que súbitos efeitos” (Rivera, 2007, p. 21).

A imagem, portanto, apresenta-se enquanto uma visualidade opaca, que revela e, ao mesmo tempo, encobre algo, não deixando espaço para leituras unificadas. É nesse encontro entre observador e obra, no qual ocorre um descentramento, uma fissura, uma torção, que se abre espaço para diversas formas simbólicas, de (re)criação. O campo do olhar converte-se em uma arena de encontro e desencontro entre sujeito e objeto.

Segundo Rivera (2002), "olhar é se olhar, fazendo-se presa de um suspense, um instante antes já diante da terrível, inquietante e estranha percepção. Ou: olhar é se fazer olhar e fazendo-se olhar, fazer-se castrar e não-castrar, a um só tempo" (pp. 58-59). Assim, ao contemplar um objeto artístico, não estamos imunes aos efeitos do inconsciente. Ele participa e intervém no nosso olhar, introduzindo no campo da visão um hiato, um desarranjo que tira do sujeito a garantia de ser o senhor de seu olhar. O espelho se estilhaça quando do encontro com o desamparo das significações imediatas, quando do encontro com o estranho. Rivera, citada por Diógenes (2017, p. 261) assinala ainda que "o sujeito-olho não está numa posição autônoma em relação ao que se vê, ao mundo, mas está tomado no campo do olhar, assujeitado por ele: no que vemos, insidiosamente somos também olhados".

No tocante às autorrepresentações contemporâneas - sendo o fenômeno selfie seu emblema máximo - evidencia-se, na maioria dos casos, a intenção de exibir uma determinada formatação do eu congelada no semblante da felicidade ou da vítima, isto é, uma história fechada num determinado sentido, colocando em cena

a ânsia de tapar os buracos, o esforço de não permitir as interferências do vestígio do real. Esse jogo da transparência, de "tudo mostrar", na verdade, é uma farsa. Essa aparência de revelação do "original" empobrece, esvazia a dimensão da arte. (Diógenes, 2017, p. 261)

A distância que existe entre o "original" e sua representação "é a condição para criação das imagens-vertigem, imagens com fendas, rasgos, o que possibilita ao sujeito receptor ser fisgado, capturado, enlaçado" (Diógenes, 2017, p. 262). Nesse sentido, temos uma narrativa que se constitui enquanto desarticuladora de uma pretensa totalidade subjetivista, fundada no eu, que visa tudo explicar (Rivera, 2014). 
Refletir sobre a exibição de si presente no fenômeno selfie a partir da interface entre psicanálise e arte coloca em cena as disputas políticas da imagem, isto é, "as resistências aos ideais de nossa época" (Marsillac et al., 2018, p. 70). Com isso, restaura a ideia de que "o homem é livre por sua fala e de que seu destino não se restringe a seu ser biológico" (Roudinesco, 2000, p. 9).

Ao abordar a noção de verdade em psicanálise é imprescindível ter em conta a dimensão inconsciente. Isto implica estar advertido de que, em psicanálise, a verdade estrutura-se enquanto ficção, sendo, portanto, uma verdade mítica (Lacan. 1954/2008). Nesse sentido, se é possível falar em alguma verdade humana, "é da verdade inconsciente que se trata" (Marsillac et al., 2018, p. 70).

Ressaltar a singularidade do sujeito, por meio do campo da psicanálise e da arte contemporânea, pode proporcionar uma maior abertura para se questionar a lógica da homogeneização das diferenças, tão presente em nosso tempo, assim como para restituir o valor da enunciação, das trocas e da experiência (Marsillac et al., 2018).

A obra de arte é capaz de apresentar ao sujeito um símbolo do vazio, a expressão de algo que não pode ser dito, que está aberto a uma pluralidade de significações. É por meio do contato com o que está fora de nós, o estranho, "que podemos fazer furo na repetição, desfazer a forma, tornando-se impossível sustentar uma unidade que não há” (Marsillac et al., 2018, p. 71).

Analisar uma obra de arte sob o prisma da psicanálise não implica em uma apreensão totalizante dos sentidos. Ao contrário, a psicanálise suscita o movimento crítico, sustentado por uma ética do desejo. A incompletude, a marca inexorável dos sujeitos, nos posiciona frente a frente com a cisão, "com aquilo que é da ordem do furo e da divisão" (Marsillac et al., 2018, p. 72).

Lacan, em 1954, já nos dizia que "o sujeito tem sempre uma relação antecipada com sua própria realização, que o lança de volta ao plano de uma profunda insuficiência e revela nele uma rachadura, um dilaceramento original" (p. 41). É por esse motivo que, em psicanálise, se diz que a experiência humana é sempre "não-toda", permeada por hiatos, parcial, e que "as tentativas de compreensão totalizante excluem a posição do sujeito" (Marsillac et al., 2018, p. 72).

Freud (1919/2007b), em seu clássico texto $O$ estranho, se debruça sobre investigações que estabeleciam diálogos entre a psicanálise e a estética. Nessa incursão, o autor reflete para além de uma teoria do belo, "pois se ocupa, no campo da estética, sobre o que nos é inquietante, estranho" (Marsillac et al., 2018, p. 75). Freud busca identificar as especificidades desse elemento de inquietante estranheza que se apresenta na experiência do olhar, despertando no sujeito sentimentos de angústia e horror. Nessa investigação, conforme nos lembra Marsillac et al. (2018), dois caminhos são vislumbrados por Freud, que, no entanto, levam a um mesmo lugar.

A inquietante estranheza, segundo Freud, seria aquela "espécie de coisa assustadora que remonta ao que é há muito tempo conhecido, ao bastante familiar. Como isto é possível, sob que condições o familiar pode tornar-se inquietante, assustador, deverá ser mostrado" (Freud, 1919/2007b, p. 331). Nesse sentido, a experiência do estranhamento se inicia - mas não se esgota - "quando o olhar da dedução de sentidos não dá conta de compreender uma imagem, quando a imagem nos aponta para uma falta a ser constitutiva do sujeito que olha e que passa, então, a ser olhado" (Marsillac et al., 2018, p. 76).

O olhar, sob o prisma da psicanálise, está inserido no campo das pulsões (Freud, 1915/2007) e "tem, como um de seus destinos, a reversão ao seu oposto. Nesse sentido, somos interrogados por aquilo que olhamos. Deparar-se com a inquietante estranheza da obra assinala o lugar que suscita a angústia, que nos interroga" (Marsillac et al., 2018, p. 76). Ao articularmos a produção de sentidos a partir do encontro entre a inquietante imagem e o olhar, percebemos um aspecto central na relação entre o corpo e o outro (Marsillac et al., 2018).

Marsillac et al. (2018) nos recorda que a suposta completude das imagens ofusca a carência de ideais simbólicos compartilhados, culminando, em nosso tempo, em uma fragilização da função paterna. Nesse sentido,

O culto da normalidade e da perfeição produzem ódio à diferença e agravam o individualismo, no qual se pressupõe prescindir do laço social. O domínio da lei sucumbe ante a promessa de superação constante. Os ideais de completude atrelados ao corpo carecem de sustentação simbólica e tendem a certa homogeneização, ao apagamento das diferenças, aguçando a agressividade, que se transforma em violência ao outro, que supostamente poderia responder a esse Outro não barrado. (Marsillac et al., 2018, p. 79)

A arte contemporânea nos inquieta, perturba nossos ideais, coloca em cena um estranho, que nos conduz à angústia, nos confrontando com uma perda. A arte, assim, é capaz de fomentar a perspectiva psicanalítica de que "nosso corpo se constitui na relação com o outro e com o Outro, sem tamponar a agressividade que está atrelada a esse processo" (Marsillac et al., 2018, p. 79). O mal-estar comparece, uma vez que reconhece o valor dos traços simbólicos transmitidos pela cultura, revelando, sem cessar, a incompletude do corpo. É no instante em que nos deparamos com a perda, com a precariedade em nós mesmos, que se possibilita a transformação do eu e do corpo. Nesse sentido, possibilita-se uma torção do corpo ideal ao ideal do corpo. Com a psicanálise, podemos admitir "que é no encontro entre o imaginário, o simbólico e o Real do corpo que se constroem ideais de corpos singulares e parciais, tendo como correlatos a sustentação da diferença no laço social" (Marsillac et al., 2018, p. 79). 


\section{Por uma Estética do Atrito}

De que maneira é possível fazer laço com o radicalmente diferente, com o estrangeiro? Sobre essa indagação, constatamos, de antemão, que a própria ideia do laço supõe uma alteridade, isto é, não há laço se não através do encontro com aquilo que não sou eu. Ainda que sempre busquemos estabelecer vínculos com aqueles que consideramos ser nossos semelhantes, aqueles que compartilhem de nossas ideias e aspirações, sempre temos uma alteridade como referência, isto é, "somos semelhantes porque somos diferentes de alguém", que, em geral, desqualificamos. Essas aproximações por semelhança são de ordem narcísica, calcadas numa diferença entre que tipo de pessoa seria melhor ou pior. Desse modo, consideramos como o grande desafio o laço com a alteridade, fazendo da diferença algo que não seja classificatório, que não silencie e desmereça o outro.

Freud (1930/2007d), ao tratar do "narcisismo das pequenas diferenças", sublinha que, mesmo dentro de um grupo aparentemente semelhante, o sujeito precisa se singularizar. Em meio às disputas identitárias, é justamente quando a diferença é pequena (e não quando é acentuada), que o outro se torna alvo de intolerância. Quando territórios que deveriam estar bem apartados se aproximam demasiadamente, trazendo à tona "as insígnias da diferença", a intolerância passa a ser convocada a restabelecer uma discriminação, no duplo sentido da palavra, sem a qual as identidades ficariam muito ameaçadas (Kehl, 2015).

Entretanto não cabe outra saída que não a de me relacionar com a alteridade, o estranho, o estrangeiro que me conduz ao estranho em mim, na medida em que sou habitada pelo próprio estrangeiro, o inconsciente. A tendência de ver no outro o desagradável que é meu torna o outro insuportável. O outro é estranho porque ele é extremamente familiar, porque ele me lembra de aspectos que eu prefiro não saber de mim mesmo.

Dito isso, acreditamos que, para fazer laço com o diferente, é preciso fomentar a criação de lugares comuns; espaços que não são nem meus, nem do outro; territórios em que possamos coexistir, tomando a alteridade como potência criadora de cultura, de novas modalidades de relações, de novos jeitos de estar junto.

\section{Arte Contemporânea e Estéticas Subversivas}

Ao mesmo tempo em que participamos da transição das tecnologias de assujeitamento, também percebemos o surgimento de políticas de resistência que perpassam diferentes âmbitos (Bentes, 2017, p. 94). É lugar comum a interpretação sobre o contemporâneo que dá ênfase aos regimes de visibilidade ancorados na ideia da exacerbação de um individualismo narcisista. Esses discursos, embora pertinentes, por vezes nos dão a impressão de estarmos irremediavelmente fadados à catástrofe, na qual a autoexposição mediada pela lógica do espetáculo triunfaria plenamente. É precisamente no contrafluxo de certas "verdades" sobre o contemporâneo que acreditamos ser possível vislumbrar outros caminhos.

Nesse sentido, cabe recorrermos a algumas ideias de Michel Foucault (1988) para refletirmos acerca do que esse autor nomeou como "cuidado de si" e "estética da existência", ideias valiosas para a problematização das autorrepresentações da era selfie.

Foucault (1988) introduz, ao final de seu percurso teórico, o conceito de estética da existência. Para o autor, é um processo que resulta do cuidado de si, isto é, "esse trabalho sobre si mesmo que produz vidas-linguagens, modos de vida plurais, experiências de liberdade, que muitas vezes divergem dos padrões sociais" (Bentes, 2017, p. 95). Entretanto é importante esclarecer que o cuidado de si e a estética da existência não se tratam de um profundo processo de mergulho interior. De modo distinto, o sujeito "é pensado e pensa a partir de sua trama de relações, redes de significações, agentes, dispositivos. O sujeito emerge como efeito, constituído na e pela linguagem” (Bentes, 2017, p. 95).

Com o cuidado de si, o sujeito volta-se para ele mesmo, devolvendo ao mundo um melhor agir. Esse sujeito (autor) reflexivo é aquele que faz de si, do seu corpo, da sua vida a matéria de uma estetização contínua. Afasta-se, portanto, da figura da celebridade, marcada pela lógica do espetáculo; pelo contrário, são sujeitos que, em seus processos de estetização em fluxo de suas vidas, promovem fissuras nos discursos normativos.

A pesquisadora Ivana Bentes (2017), na esteira do pensamento de Foucault, assinala que a vida compreendida como obra de arte e estetizada abre caminhos diversos de expressão e experimentação, que muitas vezes se chocam com os padrões e normas sociais, mercadológicas, religiosas etc. Para que essa abertura seja promovida, é preciso, segundo a autora, "fazer um trabalho de autorreflexão e autoperformação, o cuidado de si que vai produzir processos de subjetivação em que é possível fazer ver o que não víamos, criar suas próprias regras de existência” (Bentes, 2017, p. 94).

Ao estabelecermos um diálogo entre as ideias de Foucault e a problemática das novas tecnologias e redes sociais, é possível notar que as estéticas das existências operam na construção de um ativismo que, embora faça referência "às questões identitárias, de gênero, de etnia, se valem do efeito rede e processos de subjetivação em rede para produzirem imagens, narrativas e discursos disruptivos que apontam para uma experiência e proposições não essencialistas de sujeito" 
(Bentes, 2017, p. 95). Utilizar as redes sociais como ferramenta na produção de si não se trata de apresentar ao mundo uma representação hipertrofiada do eu, marcada por traços identitários, "mas produzir processos de subjetivação disruptivos e passar do microcosmo das performações à disputa dos territórios e cidades" (Bentes, 2017, p. 95).

Assim, acrescentamos a essa perspectiva, o potencial da arte como meio disruptivo, causador de inquietações, desestabilizador de certezas, capaz de nos colocar diante daquilo que nos é estranho, mas, ao mesmo tempo, familiar. Momento em que a obra nos devolve o olhar, em que somos interpelados pelo que vemos.

A arte contemporânea ampliou seus espaços de atuação - ultrapassou as paredes dos museus e galerias, explorando novos formatos e ambientes, como o ciberespaço. Nesse contexto, podemos situar o trabalho da artista carioca Aleta Valente, que frequentemente se utiliza das redes sociais digitais para desenvolver projetos artísticos, alinhados a uma ideia de resistência aos discursos docilizantes e patriarcais.

Aleta parece nos questionar: "quanta perturbação o corpo de uma mulher ainda pode causar?". A artista e ativista apropria-se das redes sociais, em especial do Instagram, desde janeiro de 2015, para dar vida a seu avatar denominado "Ex-Miss Febem", nome inspirado na música Kátia Flávia, de Fausto Fawcett. Antes de se considerar uma artista visual, Aleta trabalhou com cinema, tendo sido personagem do documentário Jogo de Cena (2007) de Eduardo Coutinho, no qual mulheres narram suas histórias de vida e atrizes interpretam a seu modo essas histórias, borrando as linhas que separam ficção de realidade. Sobre a participação no filme de Coutinho, Aleta comenta em entrevista:

Todo o desdobramento, de ver as pessoas na première rindo ou fazendo comentários, foi muito brutal. Tudo do que eu queria me distanciar estava explícito ali: vulnerabilidade, pobreza, desespero, medo da loucura... Mas isso me abriu para entender também como eu represento a mim mesma. (Strecker, 2018, p. 67)

Foi justamente motivada pelas questões relativas às autorrepresentações que Aleta empreendeu em sua performanceavatar Ex-miss Febem. Em seu perfil do Instagam, Aleta utiliza-se de sua persona para publicar imagens, memes e fotografias para construir seu trabalho. A artista, em seu processo, questiona estereótipos, utilizando a internet, o humor e as câmeras de celular, lançando mão constantemente da "autoironia, do deboche e da transgressão para produzir um curto-circuito nos discursos" (Bentes, 2017, p. 100). Desse modo, explora "profundamente a dinâmica e a interatividade das redes sociais, onde causa furor e atrai tanto ódio quanto seguidores" (Strecker, 2018, p. 66).

Ivna Bentes (2017) ressalta que Ex-Miss Febem constrói autoimagens seriais, debocha da autorrepresentação e reinventa o autorretrato, ressignificando as selfies e colocando em cena o corpo e sua imagem como meio, mídia. Além disso, "utiliza a sedução e o erotismo deslocado e fora de lugar como forma de problematizar o consumo público do corpo feminino" (Bentes, 2017, p. 100).

Ex-Miss Febem faz uso do nu feminino a exposição do sangue, dos fluxos, do corpo, nas suas formas mais cruas. Um erotismo deslocado e paródico, ao performar cada cena com caras, bocas e poses de uma sensualidade standard e reproduzida aos milhões com o advento das selfies, um processo de autorrepresentação, narração de si, que atingiu um estágio massivo. Trata-se nitidamente de um deslocamento do discurso pornográfico, mas também do discurso feminista essencialista. (Bentes, 2017, p. 105)

A artista mostra-se em selfies nas mais diversas poses, muitas delas supostamente sensuais, porém em cenários nada glamourosos.

Ela pode lamber a axila não depilada num vagão de trem, mostrar absorventes íntimos ensanguentados ou vestir como abadá uma camiseta com a marca Cytotec, o remédio com efeito abortivo que no Brasil só os hospitais têm direito de comprar. (Strecker, 2018, p. 66)

Aleta Valente realiza torções nos discursos hegemônicos através das interfaces tecnológicas que conectam esses corpos e discursos a uma multidão de outros corpos e dispositivos. "O uso das redes sociais, da autoetnografia visual, da incorporação de plataformas como Instagram e Facebook faz parte dessa outra ecologia discursiva" (Bentes, 2017, p. 105)

Ex-Miss Febem coloca em cena imagens de um corpo (seu corpo), que funciona como um contradiscurso. Essa postura, por vezes, provoca reações, comentários e juízos que afirmam discursos hostis e violentos sobre o corpo das mulheres. Ainda

3 O perfil @ex_miss_febem foi excluído por duas vezes pelo Instagram após ter recebido grande número de denúncias de outros usuários dessas redes, com suas regras de uso extremamente pudicas sobre a exposição do corpo humano (Strecker, 2018, p. 66). Atualmente, a artista utiliza o perfil @ ex_miss_febem 3 . 
assim, a artista insiste em apropriar-se da possibilidade de visibilidade máxima fomentada pelos regimes de "privacidade pública" nas redes sociais, para colocar em marcha uma "estética do escândalo". Em seu processo de autorrepresentação, Ex-Miss Febem faz uso da sedução, do erotismo, do humor, da inversão, do choque e o do consumo "para descontruir tabus, inventar novos lugares de fala". (Bentes, 2017, p. 97)

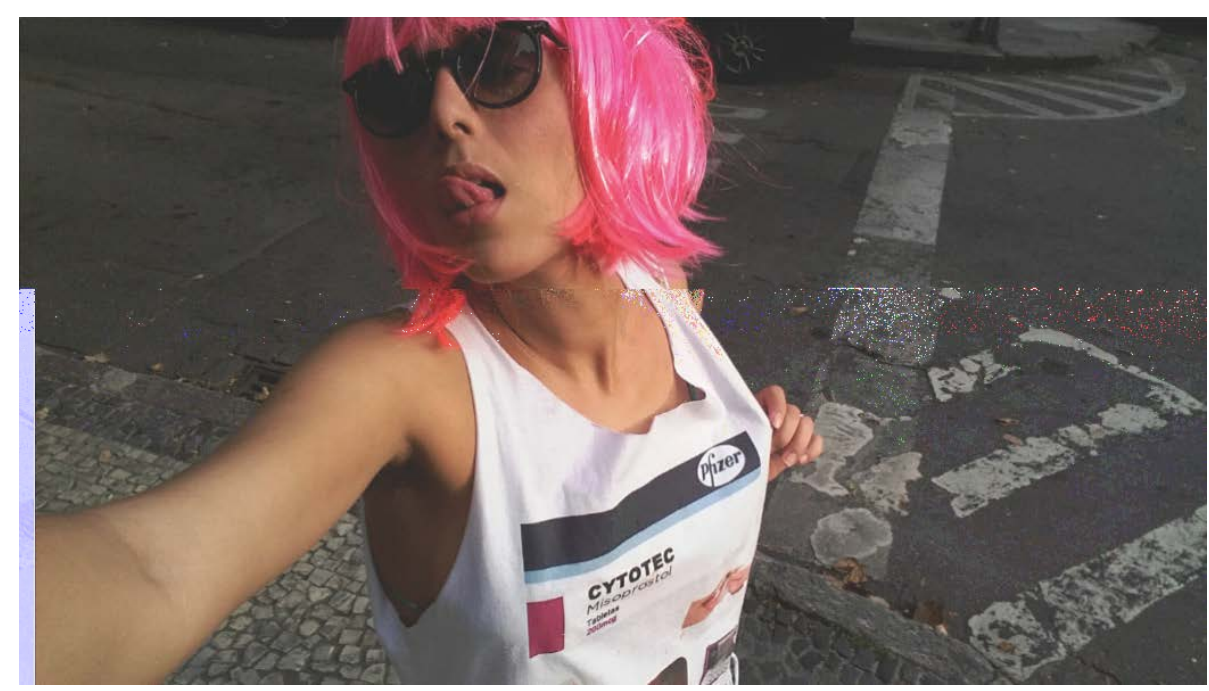

Figura 1. Aleta Valente, Ex-Miss Febem.

Na figura 1, Ex-Miss Febem realiza uma selfie em que se veste de óculos escuros, peruca e poses sensuais, vestindo uma camiseta branca estampada com o nome do medicamento Cytotec. O "Abadá do Aborto", título criado pela artista, "explicita uma prática comum entre mulheres sem poder aquisitivo para pagar uma clínica de aborto particular. Correm riscos, adoecem o corpo, vítimas de uma proibição e tabu que criminaliza e penaliza mulheres pobres” (Bentes, 2017, p. 104). A artista, ao falar de sua performance, afirma:

Meu trabalho é confrontar as formas de representação mainstream do corpo da mulher, um corpo sempre asséptico, depilado e passivo. Esse lance de pudica é foda. Mas pornografia não tem pudor e nem por isso é feminista. Acho que, quando cai nessa coisa de vadia ou moça de família, em ambos os lados há uma desumanização da mulher. De um lado, ela é um bem privado. Do outro, é uma propriedade pública. Eu falo porque não tenho amarra com instituição, não tenho amarra de trabalho, trabalho amassando limão na noite. Posso falar de assédio extensivamente. Já sofri abuso dentro do circuito da arte e continuo sofrendo. (Strecker, 2018, p. 71)

Sobre as tensões que seu trabalho provoca, a artista salienta que as críticas que recebe vêm de todos os lados. Desde fundamentalistas religiosos a pessoas ligadas ao universo das artes:

“Tô fazendo piada assim, mas não está tranquilo, não está leve pra mim. Ano passado foi muito escroto", desabafou. "Meio que tá liberado no Rio de Janeiro a pessoa entrar, pichar meu trabalho numa exposição e sair aplaudido. O nome disso é bullying mesmo, é hate mob", disse. "Não é a coisa mais agradável do mundo ter uma galera te chamando de racista dentro do próprio circuito da arte. A evidência seria que usei turbante, que usei trança", disse ela, filha de uma família multirracial. (...) “Já fui acusada de fetichizar a marginalidade, porque não existe Miss na Febem”. (Strecker, 2018, pp. 68- 69)

Aleta emprega uma estética subversiva, utilizada contra a censura, a vergonha, a vulnerabilidade dos corpos: uma "estética do escândalo" (Bentes, 2017), atuando contra o mercado da exposição, tão característica de nosso tempo. A artista tensiona os limites do mundo da arte ao situar sua produção em um atravessamento, no qual estão presentes um caldeirão de referências, tecnologia, política e vida cotidiana. Virtualidade dominada pelo discurso do consumo e da celebridade, meio em que a arte se insere provocando uma espécie de furo no discurso, dando luz a contranarrativas, questionamentos, que nos guiam a vislumbrar outros modos de ser e de viver.

É possível aproximarmos o trabalho artístico de Aleta aos dispositivos de resistência, aos processos disciplinares e à ética do desejo. Ao questionar as representações dominantes sobre os corpos femininos na contemporaneidade, as artistas 
confrontam a censura, que, no sentido psicanalítico, corresponde àquilo que nos impede de acordarmos, aquilo que deforma, aquilo que nos aliena do nosso desejo.

O que é a política senão a tentativa de uma expressão coletiva de acordo, de dissenção entre desejos? Nessa medida, a política começa com a constatação de que os desejos são diversos, são múltiplos, não são unitários, mas sim partilham uma espécie de divisão constitutiva. É por isso que a psicanálise, assim como determinadas práticas artísticas, tem afinidade com o campo da política, particularmente por meio da ideia de que não se deve pensar a sociedade como uma totalidade orgânica, harmoniosa, uma totalidade natural. Desse modo, psicanálise e política têm em comum essa orientação para o desejo.
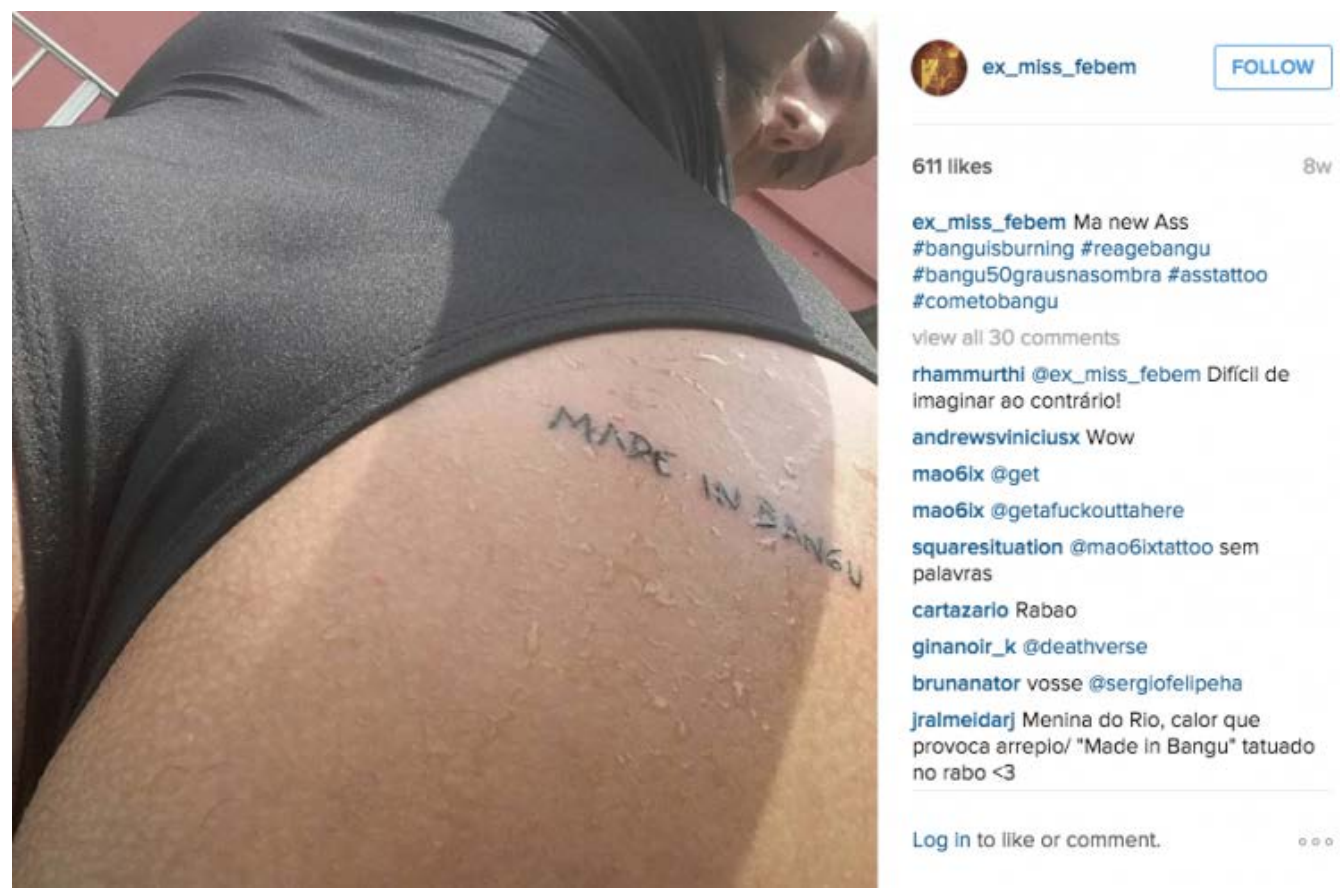

Figura 2. Aleta Valente, Ex-Miss Febem.

Vida e obra da artista Aleta Valente se confundem no trabalho de Ex-Miss Febem. Na selfie em que tatua um irônico Made in Bangu em sua bunda, a artista demarca de forma paródica sua distinção e lugar de origem. O bairro da zona oeste carioca, destacado pela artista, é utilizado para produzir uma geografia afetiva e política do subúrbio.

Amplifica o poder de posicionamento da selfie ao utilizar como cenário para seu erotismo deslocado esses anticartões postais: as ruas, lojas, vitrines e propagandas do comércio de Bangu, imagens de terrenos baldios, praças, quintais, lajes, entulhos, demolições, quartos desarrumados, banheiros, cozinhas, mesas de trabalho em desordem cotidiana. Territórios silenciados nas disputas de imaginário da cidade. (Bentes, 2017, p. 106)

Além disso, valendo-se do circuito de consumo desterritorializado das imagens produzidas pela rede, Aleta Valente brinca com referências, utilizando os códigos da cultura pop massiva: "imagens, memes, vídeos, fotografias e selfies, para produzirem uma experimentação e desencadearem processos de subjetivação e assujeitamento de toda ordem" (Bentes, 2017, p. 103). Assim, a artista atinge "nichos, segmentos, criando espaços e circuitos novos onde víamos apenas lugares de interação instantânea e comunicação" (Bentes, 2017, p. 103).

Aleta Valente instaura com seu perfil e suas imagens um processo de afirmação e autolegitimação que parece querer superar os conceitos e discursos e passa por esse novo estágio da cultura ativista e pop, a memética virótica produtora de lovers e haters instantâneos e que produz uma economia própria, outro mercado das subjetividades e das vidas-linguagens, que emergem do cotidiano, do território, de uma atenção e cuidado de si redobrados. (Bentes, 2017, p. 107)

Essas imagens também lançam luz sobre "a emergência de novos sujeitos de discurso que produzem seu lugar de fala: os 'pobre-stars', as minorias, que têm relação com toda uma cultura pop e popular brasileira, irônica e devastadora" (Bentes, 2017, p. 107). Desse modo, para se impactar com as imagens de Ex-Miss Febem não é necessário um conhecimento erudito. 
O nível de autoironia, sarcasmo e humor também demole e neutraliza os discursos de ódio, de certa forma. Mas a carga de violência, misoginia em alguns comentários, é um espelho pelo avesso de quanto as imagens são perturbadoras e impactantes. (Bentes, 2017, p. 108)

As imagens da artista, quando apresentam os fluxos cotidianos em sua crueza e potência disruptiva, "explodem os códigos e também fazem vazar todos os discursos de contenção e interdição" (Bentes, 2017, p. 108).

O conjunto de imagens de Ex-Miss Febem forma uma enciclopédia disruptiva, subversiva, perturbadora, que toca em praticamente todas as questões que importam. Desde questões de autorrepresentação, autolegitimação, autoexposição e gênero até questões como consumo, glamour, pobreza, resistência, sexualidade, sedução, sexismo, feminismo, patriarcalismo, feminismo e pósfeminismo, urbanismo, maternidade, menstruação, aborto, masturbação, marginalidade. (Bentes, 2017, p. 107)

Nesse sentido,

as imagens de Aleta Valente performam uma disputa vital, assimétrica, violenta, afetiva, de irrupção e transbordamento. Essas imagens se inscrevem em um processo experimental, tanto nas teorias de gênero quanto nas práticas de uma estética da existência em um contexto de uma polissexualidade em performação. (Bentes, 2017, p. 108)

A singularidade da artista emerge de todo esse emaranhado de referências, "dessa produção coletiva, anônima, em que cada um com seu repertório recebe uma carga de mil referências que produz um efeito singular" (Bentes, 2017, p. 108). Nesse sentido, corroboramos Pinheiro (2016) quando nos diz que "na gramática do ego editável da vida on-line, o aparente acabamento fetichista da autoimagem pode perfazer-se enquanto dobra ou potencialidade de travessia/percurso do processo de redescrição das narrativas de si, estetizantes do deslizamento metonímico sobre os objetos do desejo" (Pinheiro, 2016, p. 95).

$\mathrm{O}$ esforço reflexivo deste trabalho, que buscou analisar determinadas formas de estetização do eu na atualidade tecnológica (Pinheiro, 2016), buscou ampliar nossos olhares acerca da autorrepresentação, privilegiando uma crítica aos discursos moralizantes engendrados por instâncias de poder que visam ao controle e à docilização de corpos em nosso tempo. Nesses termos, ao refletirmos sobre as relações entre arte, psicanálise e política, buscamos evidenciar algumas nuances presentes no contemporâneo, apontando para um sentido critico, defendendo a ideia não de uma singularidade corpocentrada, na medida em que esta "trabalharia em função da falicização da diferença, de inflacionamento egoico, repetindo uma objetificação imaginária" (Pinheiro, 2016, p. 94), mas sim de uma singularidade simbolicamente sustentada, que corresponde "à possibilidade de o sujeito contar-se como menos um. Desinvestido das promessas de aprisionante completude, implicando-se na produção de destinos mais criativos à angústia de sua finitude/limite/vulnerabilidade" (Pinheiro, 2016, p. 94).

É através da identificação do sujeito à falta que a singularidade (ordenada pelo significante) ocorreria como aquela que advém do desinvestimento de emblemas fálicos. Nesse sentido, Pinheiro (2016) afirma que:

A singularidade seria experienciada como gatilho de satisfações diversas, plasticamente lançada ao fluxo metonímico do desejo. Nessa formação, encontraríamos o sujeito que ressignifica polissemicamente sua história, que imprime sua marca subversiva na realidade simbólica a que participa, como mais um representante. Num permanente movimento de ruptura à inércia do sentido, nessa organização o sujeito descobre novas formas de erotismo, de investimento na vida, no outro. (pp. 94-95)

A singularidade simbólica alinha-se à ideia de sujeito que se ocupa de sua vida como obra sempre inacabada, vislumbrando "na possibilidade de estetização da existência por sua singularidade o legado mais satisfatório a ser recoberto sob seu nome" (Pinheiro, 2016, p. 94). É por essa via que apostamos na produção de atitudes estéticas que tensionem as imagens, os lugares estabelecidos; que impliquem na dúvida sobre os discursos hegemônicos, para que assim seja possível reinventar espaços, desestabilizar as lógicas totalitárias, abrindo lugares inéditos de mundos porvir, de palavras porvir, de invenção da vida.

Se o desejo continua a ser o motor da vida, devemos, portanto, interrogar de uma forma diferente a nossa relação com o objeto, mais precisamente com os objetos de tela, apreendendo-o não somente a partir de um viés que o considera alienante, limitante, redutor do sujeito a uma imagem e um tempo ou um espaço dado pelo virtual, mas, ao contrário, como sendo capaz ele mesmo de nos oferecer a possibilidade de nos transformarmos a partir do ato de criação. 


\section{Referências}

Azevedo, A. V. (2006). Ruídos da imagem: Questões de linguagem, palavra e visualidade. In T. Rivera \& V. Safatle (Orgs.), Sobre arte e psicanálise (pp. 13-29). São Paulo: Escuta.

Azouri, C. (2014). Testemunhos de um encontro com o vazio. In A. Didier-Weill (Org.), Nota Azul: Freud, Lacan e a arte (2a ed., pp. 27-32). Rio de Janeiro, RJ: Contra Capa.

Bauman, Z. (1998). O mal-estar da pós-modernidade. Rio de Janeiro, RJ: Zahar.

Bentes, I. (2017). Biopolítica feminista e estéticas subversivas. Revista Matrizes, 11(2), 93-109.

Calligaris, C. (1994, agosto 21). Um narcísico mundo novo. Folha de S. Paulo. Link

Costa, L. B. (2009). Imagem dialética - imagem crítica - Um percurso de Walter Benjamin à Georges Didi-Huberman. In Universidade de Campinas (Org), Comunicação Científica, V Encontro de História da Arte. Campinas: Unicam.

Didi-Huberman, G. (2010). O que vemos, o que nos olha. São Paulo, SP: Ed. 34. (Originalmente publicado em 1998).

Diógenes, E.V. (2017). Narrativas (auto)biográficas no documentário brasileiro: Do privado ao público. Tese de Doutorado, Programa de Pós-graduação em Comunicação e Semiótica, Pontifícia Universidade Católica de São Paulo, SP.

Falbo, G. (2009). Psicanálise e arte: Modos de tratar o real pelo simbólico. In M. M. de Lima \& M. A. Coutinho Jorge (Orgs.), Saber fazer com o real: Diálogos entre psicanálise e arte (pp. 69-78). Rio de Janeiro, RJ: Cia. de Freud.

Ferretti, M. G. (2011). Considerações sobre a ética e a política na psicanálise. A Peste: Revista de Psicanálise e Sociedade e Filosofia, 3(1), 69-76.

Foucault, M. (1988). História da sexualidade I: A vontade de saber. Rio de Janeiro, RJ: Graal.

Freud, S. (2007a). Sobre o narcisismo: uma introdução. In Edição Standard Brasileira das Obras Psicológicas Completas de Sigmund Freud (Vol. 14, pp. 77-110). Rio de Janeiro: Imago. (Originalmente publicado em 1914)

Freud, S. (2007b). O estranho. In Edição Standard Brasileira das Obras Psicológicas Completas de Sigmund Freud (Vol. 17, pp. 237-276). Rio de Janeiro: Imago. (Originalmente publicado em 1919)

Freud, S. (2007c). Psicologia das massas e análise do ego. In Edição Standard Brasileira das Obras Psicológicas Completas de Sigmund Freud (Vol. 18, pp. 79-156). Rio de Janeiro: Imago. (Originalmente publicado em 1921)

Freud, S. (2007d). O mal-estar estar na civilização. In Edição Standard Brasileira das Obras Psicológicas Completas de Sigmund Freud (Vol. 21, pp. 73-150). Rio de Janeiro: Imago. (Originalmente publicado em 1930)

Izcovich, L. (2018). Psicanálise e Política. Revista Stylus, 36, 19-26.

Kehl, M. R. (2015, março 2). A mínima diferença [Blog]. Link

Khouri, M. G. (2015). Clínica psicanalítica e arte contemporânea. Revista Ide, 37(59), 123-128.

Kosovski, G. F. (2016). Psicanálise e arte: Uma articulação a partir da não relação em Louise Bourgeois: O retorno do desejo proibido. Revista Ágora: Estudos em Teoria Psicanalítica, 19(3), 441-455.

Lacan, J. (1966-1967). O seminário, Livro 14: A lógica do fantasma. (Inédito).

Lacan, J. (1988). O seminário, Livro 7: A ética da psicanálise. Rio de Janeiro: Jorge Zahar. (Originalmente publicado em 
1959-60)

Lacan. J. (2008). O Mito individual do Neurótico, ou, A poesia e a verdade na neurose. Rio de Janeiro: Zahar. (Originalmente publicado em 1954)

Lasch, C. (1983). Cultura do narcisismo: A vida americana numa era de esperanças em declínio. Rio de Janeiro, RJ: Imago. (Originalmente publicado em 1979)

Lipovetsky, G., \& Charles, S. (2004). Os tempos hipermodernos. São Paulo: Barcarolla.

Marsillac, A. L. M., Tancredi, T. C., Sousa, J. G. N. (2018). Políticas do corpo: Arte e Psicanálise despindo as imagens. Revista Subjetividades, 18 (esp), 68-80.

Miranda, L. L. (2007). A cultura da imagem e uma nova produção subjetiva. Revista Psicologia Clínica, 19(1), 25-39.

Pinheiro, M. (2016). A paixão pela imagem: O eu como cenógrafo das virtualidades do si mesmo. Revista Latinoamericana de Psicopatologia Fundamental, 19(1), 84-98.

Prada, J. M. (2018). El ver y las imágenes en el tempo de internet. Madrid: Akal Estudios Visuales.

Rivera, T. (2002). Arte e psicanálise. Rio de Janeiro, RJ: Jorge Zahar.

Rivera, T. (2007). O sujeito na psicanálise e na arte contemporânea. Revista Psicologia Clínica, 19(1), 13-24.

Rivera, T. (2014). Kosuth com Freud: Imagem, psicanálise e arte contemporânea. In T. Rivera (2014), O Avesso do Imaginário: arte contemporânea e psicanálise (pp. 47-79). São Paulo, SP: Cosac Naify.

Roudinesco, E. (2000). Por que a Psicanálise? Rio de Janeiro, RJ: Jorge Zahar.

Sibilia, P. (2016). O show do Eu: A intimidade como espetáculo. Rio de Janeiro, RJ: Contraponto.

Strecker, M. (2018). Aleta Valente: Suburbana, mãe solteira, feminista, artista. Revista Select, (38). Link

\section{Como citar:}

Pedrosa Filho, R. B. A., \& Teixeira, L. C. (2020). A Política das Imagens e a Ética do Desejo nas Autorrepresentações Contemporâneas. Revista Subjetividades, 20(Esp 2. O Contemporâneo à Luz da Psicanálise), e10428. http://doi. org/10.5020/23590777.rs.v20iEsp2.e10428

\section{Endereço para correspondência}

Raimundo Benone de Araújo Pedrosa Filho

E-mail: benonepedrosa@gmail.com

Leônia Cavalcante Teixeira

E-mail: leonia.ct@gmail.com 